Low molecular weight thymic factor stimulates the suppressor function of T-lymphocytes, increases cAMP content (but not cGMP) in lymphocytes and inhibits histamine release from sensitized basophils. The mechanisms of LTF action are discussed.

Key words: Basophils, Cyclic nucleotide, Lymphocytes, Thymic factor

\section{Low molecular weight thymic factor inhibits histamine release from basophils}

\author{
S. I. Yalkut, ${ }^{1, C A}$ E. V. Gulling, ${ }^{2}$ T. Yu. Gots, ${ }^{2}$ \\ S. A. Kotova, ${ }^{1}$ O. B. Belova, and \\ V. Ch. Premyslov ${ }^{1}$
}

${ }^{1}$ R.E. Kavetsky Institute of Experimental

Pathology, Onkology and Radiobiology, Acad. Sci. of Ukraine, 252650, ul. Vasilkovscaja 45, Kiev, Ukraine, ${ }^{2}$ Kiev Advanced Training Institute for Physicians, Clinical Immunology and Allergology Department, 252112, Dorogozshitskaya 9, Kiev, Ukraine

${ }^{\mathrm{CA}}$ Corresponding Author

\section{Introduction}

Low molecular weight thymic factor (LTF) was obtained by dialysis of calf thymus extract. The molecular weight of LTF was less than $1000 \mathrm{Da}$. As shown previously, the LTF contained one or more active substances, in particular a non-peptide structure with a mitogenic effect on mouse thymocytes. ${ }^{1}$ LTF suppresses IgE-antibody synthesis in experimental systems. ${ }^{2}$ Rat thymocytes treated with LTF inhibit reagin synthesis after administration to previously sensitized rats. The peculiarities of LTF's anti-allergic effect were determined by comparison with other anti-allergic agents, such as anti-histamines and basophil stabilizers. However, the mechanisms by which LTF influences T-suppressor function and other anti-allergic effects, are unclear. These questions have been studied in the present work.

\section{Materials and Methods}

Effects of LTF on lymphoid cells: The effects of LTF on lymphoid cells were studied in eight healthy persons and eleven patients with reaginic hypersensitivity. Peripheral blood mononuclear cells were isolated from $20 \mathrm{ml}$ of heparinized venous blood by Ficoll-Hypaque gradient centrifugation. ${ }^{3}$ The viability of cells was always more than $95 \%$ as determined by the Trypan blue exclusion test.

The mitogenic effect of LTF, compared with that of phytohaemagglutinin (PHA, Difco), was determined. Lymphoid cells $\left(2 \times 10^{6}\right.$ per $\left.\mathrm{ml}\right)$ in
$50 \mu$ complete RPMI 1640 medium were incubated in each well of round-bottomed microtitre plates, with $50 \mu \mathrm{l}$ PHA $(30 \mu \mathrm{g} / \mathrm{ml})$ or $10,20,50$ or $100 \mu \mathrm{g} / \mathrm{ml}$ of lyophilized LTF, in a humidified atmosphere containing $5 \% \quad \mathrm{CO}_{2}$, at $37^{\circ} \mathrm{C}$ for 24-72 h. Six h before the end of incubation each well was pulsed with $8 \mu \mathrm{Ci}$ of ${ }^{3} \mathrm{H}$-thymidine in $50 \mu \mathrm{l}$ medium. Control cells were not pulsed with thymidine. Then cells were harvested onto glass fibre filter paper and radioactivity was measured as $\mathrm{cpm}$ in a liquid scintillation counter. All assays were performed in triplicate.

The LTF suppressor effect was studied as described previously. ${ }^{4}$ The $2 \times 10^{6}$ lymphoid cells were cultured with $30 \mu \mathrm{g} / \mathrm{ml}$ Concanavalin A (Con A, Sigma) for $48 \mathrm{~h}$ and LTF at 1,20 or $100 \mu \mathrm{g} / \mathrm{ml}$ for 24,48 or $72 \mathrm{~h}$ in a humidified $5 \%$ $\mathrm{CO}_{2}$ atmosphere. Control cells were incubated without Con A or LTF under similar experimental conditions. Suppressor assays were performed using culture medium in round-bottom microtitre plates, in triplicate. Each well contained $1 \times 10^{5}$ of freshly separated autologous mononuclear cells and $100 \mu \mathrm{l}\left(1 \times 10^{5}\right)$ of mitomycin C treated suppressor or control cells. Cultures were stimulated with PHA and investigated as described above. The results of Con A-induced suppressor cell activity are expressed as:

$$
\% \text { Suppression }=\left(1-\frac{S_{p}-S}{C_{p}-C}\right) \times 100
$$

where $S_{p}$ is cpm of cells treated with PHA in the 
presence of Con A or LTF; $S$ is cpm of Con A or LTF-induced cells; $C_{p}$ is cpm of cells treated with PHA only; $C$ is cpm of untreated, control cells.

The cyclic nucleotide content in lymphocytes was determined using a radioassay method with kits supplied by Amersham, UK. Picomole concentrations of cyclic nucleotides may be determined by this method. Before cyclic nucleotide determination cells were incubated with 20 or $100 \mu \mathrm{g} / \mathrm{ml} \mathrm{LTF}$.

Differentiation of cells in culture was carried out by histochemical methods as described previously. ${ }^{5}$

Effects of LTF on histamine release: The effects of LTF on histamine release from human basophils were studied in 22 patients with atopic asthma. Skin prick tests showed that all patients had positive reactions to house dust or other allergens. None of the patients had received any drugs during the week before examination.

Basophil leukocytes were separated from $10 \mathrm{ml}$ peripheral blood according to the method of Day. ${ }^{\circ}$ The cell concentration was adjusted to 4-6 $\times 10^{6}$ leukocytes $/ \mathrm{ml}$ (10-30\% basophils), then the cells were resuspended in $10 \mathrm{ml}$ Tris buffer. Aliquots $(400 \mu \mathrm{l})$ were incubated for $40 \mathrm{~min}$ at $37^{\circ} \mathrm{C}$ with different concentrations of dust allergen extract and LTF $(20 \mu \mathrm{g} / \mathrm{ml})$. Histamine release was stopped by rapidly cooling in ice. Each experiment was done in triplicate. Then the cells were centrifuged and the histamine content of supernatants and cells was measured using an Hitachi spectrofluorometer and according to the method of Shore et al., as modified by Bergendorf and Uvnas. ${ }^{7}$ : The amount of histamine released after treatment was compared with the total amount of histamine extracted from cells lysed by heating in a boiling water bath for $5 \mathrm{~min}$. Results were expressed as a percentage.

Statistical comparisons were performed by the paired Student's $t$-test.

\section{Results}

The results show that lymphocytes treated with LTF alone do not undergo a mitogenic effect similar to that caused by PHA. Figure 1 shows 600 $1050 \mathrm{cpm}$ in cells treated with LTF and in nonstimulated cells, compared with $6000-7000 \mathrm{cpm}$ in cells treated with PHA. As seen from the results in Table 1, LTF also stimulates a suppressor effect in lymphoid cultures treated with PHA. This suppressor effect was a maximum after $48 \mathrm{~h}$ incubation, at a dose of $20 \mu \mathrm{g} / \mathrm{ml}$.

As shown in Fig. 2 the suppressive effect occurred in both healthy people and in allergic patients. LTF caused between 13 and $22 \%$

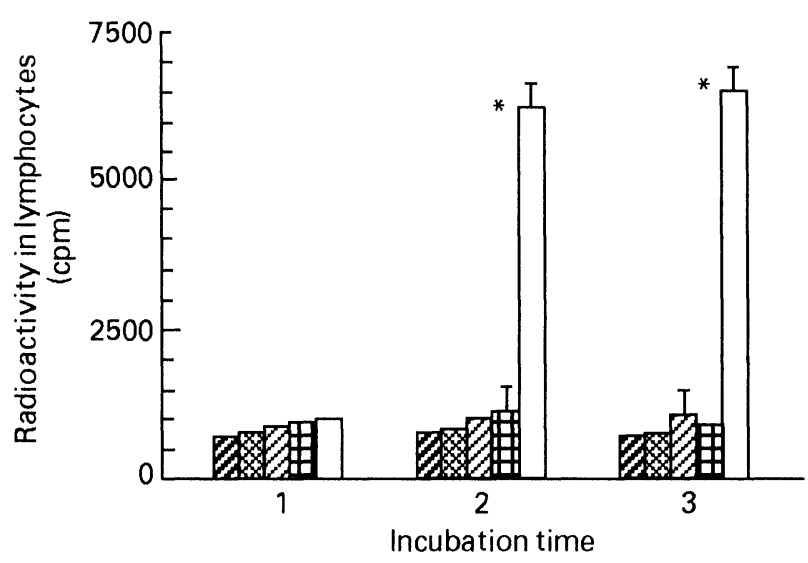

FIG. 1. Transformation of lymphocytes after reaction with PHA or LTF Results are given as mean \pm S.E.M. ${ }^{*} p<0.01 . \square, \mathrm{PHA} ; \square, 10 \mu \mathrm{g} / \mathrm{ml}$ LTF; $20 \mu \mathrm{g} / \mathrm{ml}$ LTF; $2,50 \mu \mathrm{g} / \mathrm{ml}$ LTF; $\boxplus, 200 \mu \mathrm{g} / \mathrm{ml}$ LTF.

Table 1. LFT-induced suppressor activity in cells of healthy persons

\begin{tabular}{rrrr}
\hline & \multicolumn{3}{c}{ Incubation time with LTF $(\mathrm{h})$} \\
\cline { 2 - 4 } $\begin{array}{c}\text { LTF dose } \\
(\mu \mathrm{g} / \mathrm{ml})\end{array}$ & \multicolumn{1}{c}{24} & \multicolumn{1}{c}{48} & \multicolumn{1}{c}{72} \\
\hline 1 & $8.1 \pm 1.1$ & $12.6 \pm 1.4^{*}$ & $11.3 \pm 1.5$ \\
20 & $11.4 \pm 1.5$ & $22.0 \pm 1.6^{* *}$ & $20.2 \pm 1.7^{* *}$ \\
100 & $8.0 \pm 1.5$ & $11.1 \pm 1.4$ & $11.3 \pm 2.1$ \\
\hline
\end{tabular}

Results are expressed as mean \pm S.E.M. suppression index $* * p<0.01, * p<0.05$ compared with initial level.

suppression at doses of 20 and $100 \mu \mathrm{g} / \mathrm{ml}$, respectively, which was similar to that caused by Con A (25\% suppression at a dose of $30 \mu \mathrm{g} / \mathrm{ml})$. Incubation of lymphoid cells with LTF stimulated the release of cAMP, with the maximum effect occurring after $24 \mathrm{~h}$ (Table 2). Significant changes of cGMP levels were not observed.

Signs of monocyte-macrophage activation in lymphoid cell cultures incubated with LTF were demonstrated histochemically. Results showed large cells with nuclei often eccentrically located as irregular forms, and an azurophylic vacuolized cytoplasm. The PAS reaction for glucogen gave moderate results-in some cells solitary granules

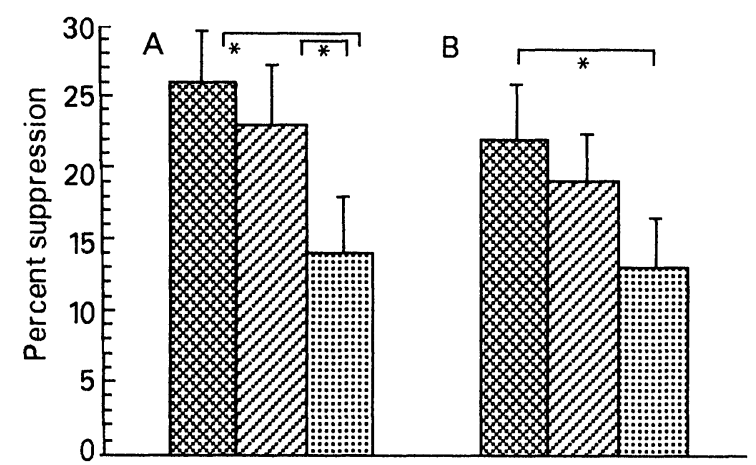

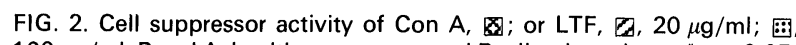
$100 \mu \mathrm{g} / \mathrm{ml}$. Panel A, healthy persons; panel B, allergic patients. ${ }^{*} p<0.05$. 
Table 2. Cyclic nucleotide levels in lymphocytes stimulated with LTF

\begin{tabular}{lcrcc}
\hline & & \multicolumn{2}{c}{ Incubation with LTF $(\mathrm{h})$} \\
\cline { 4 - 5 } $\begin{array}{c}\text { Cyclic } \\
\text { nucleotide }\end{array}$ & $\begin{array}{c}\text { Initial } \\
\text { level }\end{array}$ & $\begin{array}{c}\text { LTF dose } \\
(\mu \mathrm{g} / \mathrm{ml})\end{array}$ & 24 & 48 \\
\hline cAMP & $4.9 \pm 1.0$ & 20 & $10.1 \pm 1.3^{* *}$ & $9.4 \pm 1.0^{* *}$ \\
& & 100 & $11.6 \pm 1.7^{* *}$ & $10.9 \pm 1.1^{* *}$ \\
cGMP & $0.4 \pm 0.05$ & 20 & $0.4 \pm 0.08$ & $0.44 \pm 0.1$ \\
& & 100 & $0.5 \pm 0.1$ & $0.45 \pm 0.07$ \\
\hline
\end{tabular}

Results are expressed as mean \pm S.E.M. pmol $/ 10^{6}$ lymphocytes.

$* * p<0.01$ compared with initial level.

appeared. Staining for lipids by Sudan Black showed the accumulation of solitary granules, or the lack of them. The reaction for peroxidase was weak, while the reaction for acid phosphatase was characteristic of monocytes. These signs differentiate activated cells from lymphocytes and neutrophils, and show a monocyte-macrophage origin.

The effects of LTF on histamine release are given in Fig. 3. As shown, incubating sensitized basophils with allergens stimulated histamine release from the cells. The addition of LTF to this system blocked the reaction in a dose-dependent manner.

\section{Discussion}

The present data indicate that LTF does not stimulate a cell transforming effect in lymphoid cells of peripheral blood. In the same cellular cultures the positive cell transforming effect of PHA and Con A was observed. From the data it may be concluded that (1) LTF does not possess a mitogenic effect for peripheral blood cells; and (2) LTF stimulates the T-suppressor function. These facts agree with data presented in Table 2 concerning the changes in intracellular cyclic nucleotide concentrations of lymphocytes incubated with LTF.

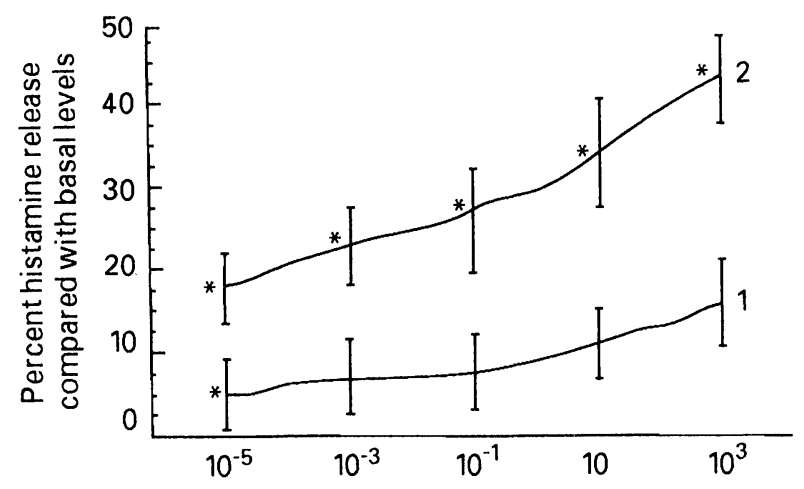

FIG. 3. The influence of LTF on histamine release from sensitized basophils. Results are given as mean + S.E.M. ${ }^{*} p<0.05$ compared with the control group. Curve 1, with LTF; curve 2, without LTF.
It is well known that the stimulation of lymphocyte proliferative activity is accompanied by an increase in cGMP concentration. ${ }^{8}$ However, such an increase was not observed in our studies. On the other hand, an increase in cAMP concentration was found under the same experimental conditions. This phenomenon characterises the differentiation and stimulation processes of T-lymphocyte effector functions. It would be interesting to compare these results with the effects of dialysable leucocyte extracts of peripheral blood, which also demonstrate the cAMP accumulation in cells. ${ }^{9}$ It was assumed that biological effects of dialysable leucocyte extracts mainly depend on low molecular weight substances of long-living lymphocytes. ${ }^{10}$ The present findings may support this hypothesis. Moreover an important conclusion which follows from this study is the possibility of using LTF for determining functional lymphocyte activity.

The activation of monocyte-macrophage elements noted on the basis of morphological characteristics suggests an interesting role of these bodies in the regulation of immune response. The possible pathway may be connected with $\mathrm{T}$ lymphocyte stimulation and production of macrophage activation factor. However, direct action of LTF on macrophages and activation of Tlymphocytes as a result of interleukin-1 and deoxycytidine accumulation cannot be excluded. It was found that deoxycytidine accumulation in thymocytes and macrophages of mouse thymus removes the restriction of ribonucleoside diphosphoreductase activity, and thymocyte proliferative activity depends on this enzyme. ${ }^{11}$ The stimulating action of LTF on thymus cell proliferation demonstrated previously ${ }^{1}$ may be associated with activation of macrophagal elements and with deoxycytidine accumulation. It has been shown that deoxycytidine does not influence the proliferative activity of peripheral blood cells. ${ }^{12}$ It follows that the metabolism of deoxycytidine and other pyrimidine and purine nucleosides may be associated with the influence of LTF either on thymocytes at different stages of maturation, or on mature lymphocytes of peripheral blood.

The absence of a proliferative effect by LTF on lymphocytes of peripheral blood makes it necessary to look for other methods by which the regulatory action of LTF occurs. It may be that cell membranes are stabilised, and that this is connected with changing cyclic nucleotides levels. These effects are characteristic of different cell types and are determined by receptors for various low molecular weight substances; for example, adenosine and drugs which react in this way. ${ }^{13}$ The present data, which show a direct inhibitory effect of LTF on basophil degranulation and histamine release, may be explained by this fact. 
In conclusion, it may be said that LTF stimulates the anti-allergic effects on the different target cells. The mechanisms of LTF action compared with those of known anti-allergic effects provide questions for future investigations.

\section{References}

1. Bezvershenko IA, Goidash MM, Premyslov V. Adenylic acid catabolism in thymocytes of the regenerating thymus of mice. Ukrain Biochem J 1989; 61 : $52-57$

2. Bezvershenko IA, Gjulling EV, Dyugovskaya LA. Suppression of IgE-antibody production by nonpolypeptide dialysable thymic factor. Immunology 1979; 36: 229-234.

3. Boyum A. Isolation of mononuclear cells and granulocytes from human blood. Scand J Clin Lab Invest 1968; suppl: 77-89.

4. Hwang K, Fikrig SM, Friedman HM, Gupta S. Deficient Concanavalin-Ainduced suppressor-cell activity in patients with bronchial asthma, allergic rhinitis and atopic dermatitis. Clin Allergy 1985; 15: 67-72.

5. Haynoe FGJ, Quaglino D. Haematological cytochemistry. Edinburgh, London and New York: Churchill Livingstone, 1980; 320

6. Day RP. Basophil leukocyte separation from human peripheral blood: technique for their isolation in high purity and high yield. Clin Allergy 1972; 2: 205-212.
7. Bergendorf A, Uvnas B. Storage of 5-HT in rat mast cell. Evidence for anionic binding to carboxyl groups in a granule-heparine protein complex. Acta Pbysiol Scand 1972; 84: 320-331.

8. Coffey KG, Hadden EM, Lopez C. cGMP and calcium in the initiation of cellular proliferation. In: George WJ, Ignarro LJ, eds. Advances in Cyclic Nucleotide Research. New York: Raven Press, 1978; 9: 661-676.

9. Herlin T, Jensen JR, Thestrup-Pedersen K, Zachariak H. Dialyzable leukocyte extract stimulates cAMP in T-lymphocytes. Allergy 1981; 36 337-343.

10. Wilson GB, Paddock GV, Floyd E et al. Dialyzable leukocyte extracts contain thymosin. Thymus $1984 ; 6$ : 167-180.

11. Penit C, Papiernic M. Regulation of thymocyte proliferation and survival by deoxynucleosides. Deoxycytidine produced by thymic accessory cells protect thymocytes from deoxyguanosine toxicity and stimulates their spontaneou proliferation. Eur I Immunol 1986; 16: 257-263.

12. Scharenberg JG, Rijkers GT, Spaapen LJ et al. Different pathways for deoxyguanosine toxicity in T-lymphocytes of various developmental stages. Int J Immunopharm 1988; 10: 675-686.

13. Moroz Ch, Bessler H, Djaldetti M, Stevens RH. Human adenosine receptor bearing lymphocytes: enumeration, characterisation and distribution on peripheral blood lymphocytes. Clin Immunol Immunopathol 1981; 18: $47-53$

\section{Received 29 June 1993:}

accepted with revision 7 October 1993 


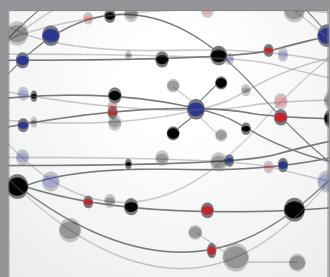

The Scientific World Journal
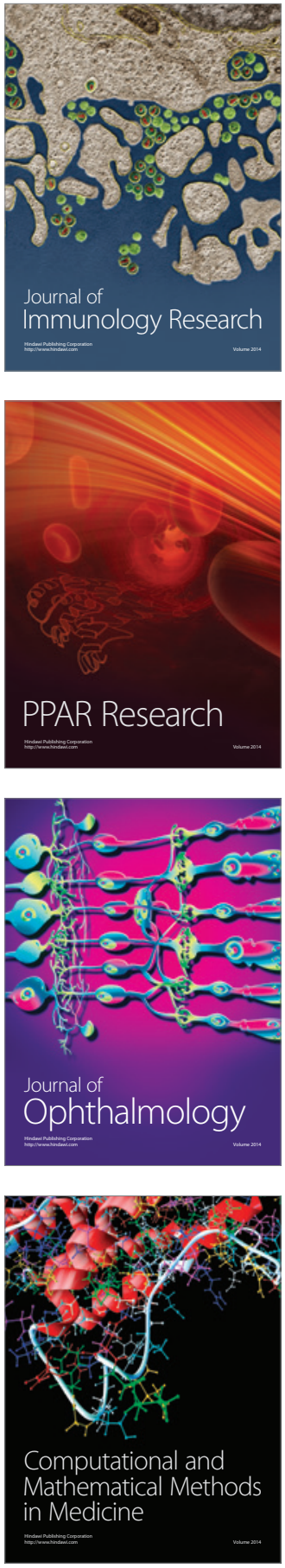

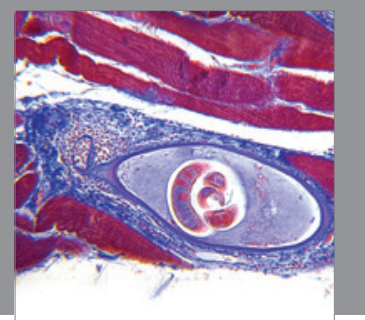

Gastroenterology

Research and Practice
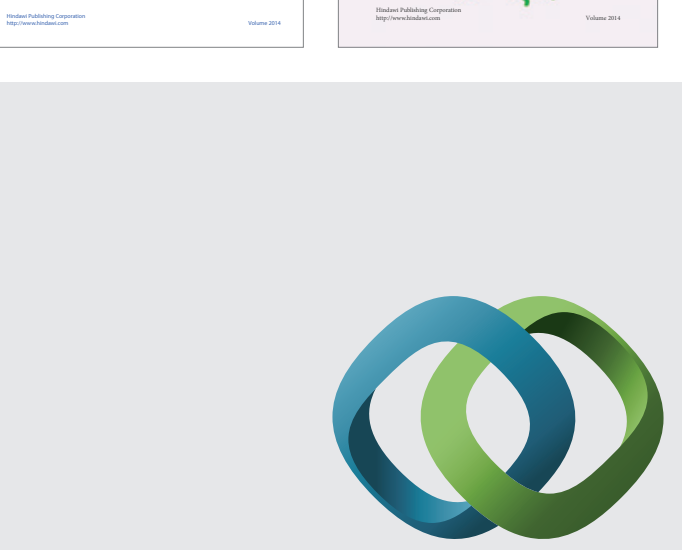

\section{Hindawi}

Submit your manuscripts at

http://www.hindawi.com
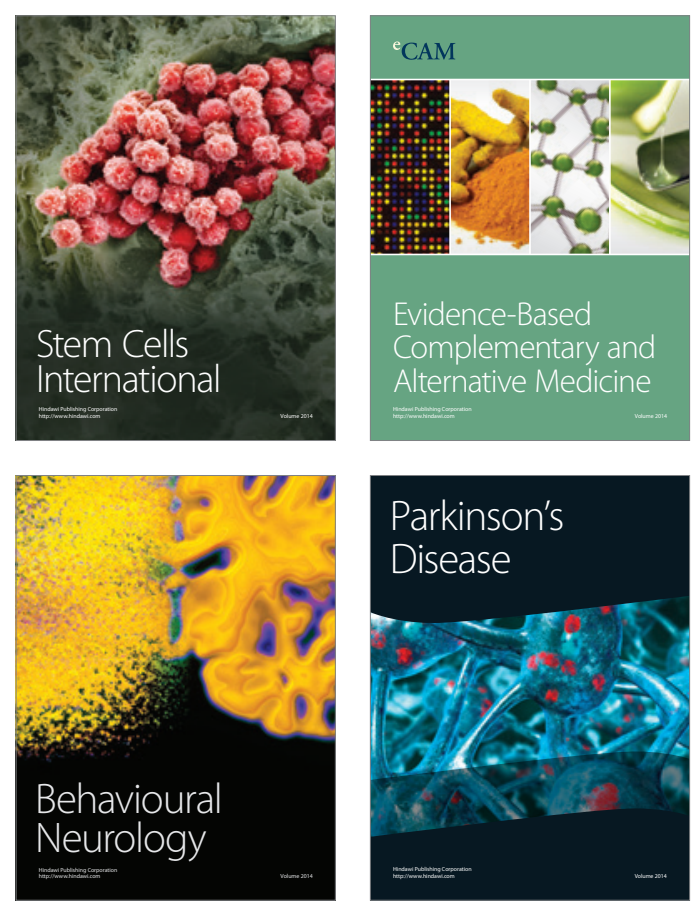

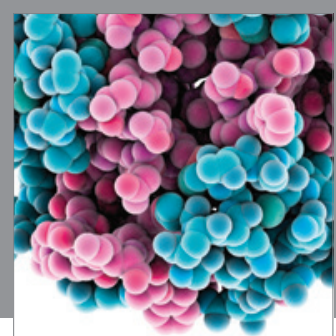

Journal of
Diabetes Research

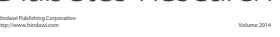

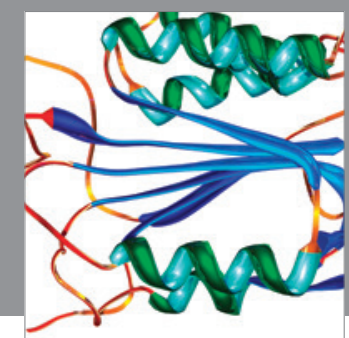

Disease Markers
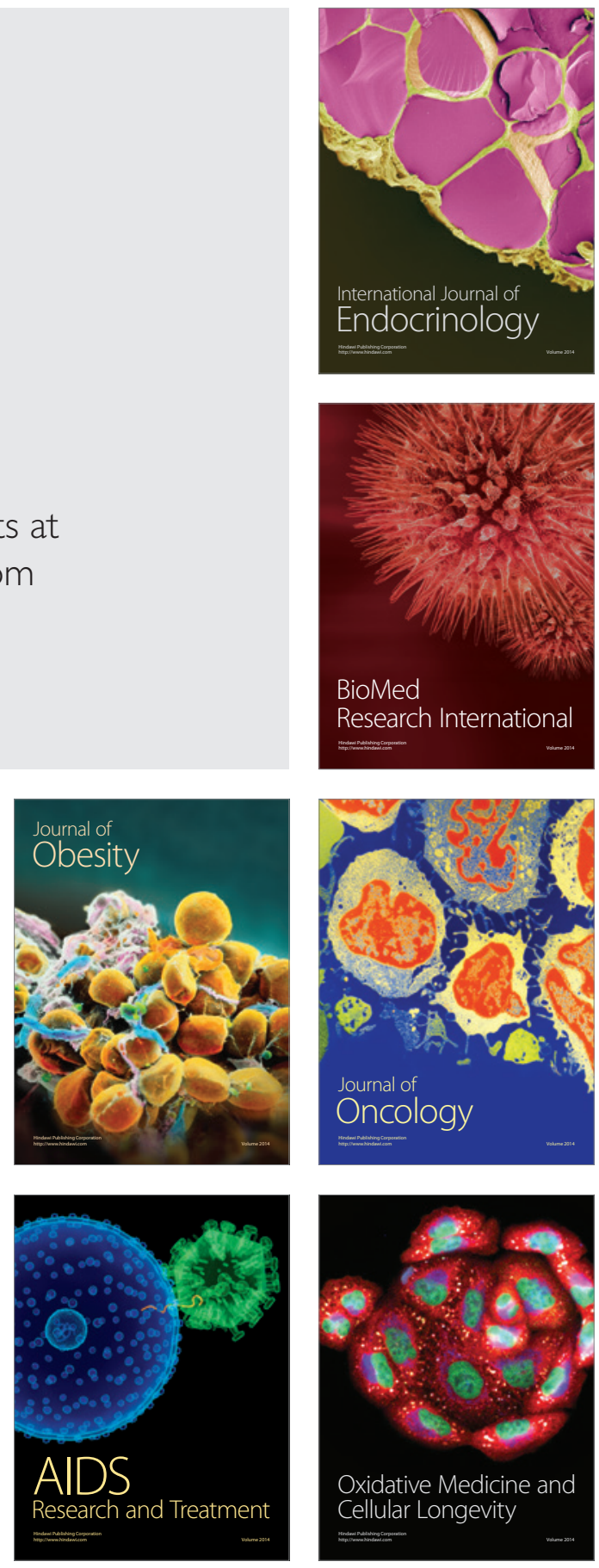